\title{
ANALISIS KESALAHAN SISWA DALAM MENYELESAIKAN SOAL CERITA SPLDV BERDASARKAN TAHAPAN NEWMAN DITINJAU DARI TIPE KEPRIBADIAN FLORENCE LITTAUER
}

\author{
Mutiara Winda Santoso*, Dinawati Trapsilasiwi, Randi Pratama Murtikusuma ${ }^{2}$ \\ Program Studi Pendidikan Matematika, Jurusan Pendidikan MIPA, FKIP \\ Universitas Jember \\ Jl. Kalimantan 37, Jember 68121 \\ E-mail: mutiara.winda11@gmail.com
}

\begin{abstract}
The aim of this qualitative research is to describe the types of student errors in solving the two-variable linear equation system story problem based on Newman's error analysis in terms of Florence Littauer's personality type. The data sources consisted of 8 students of grade IX C SMP Nuris Jember who had been taught the material of twovariable linear equation systems. The data taken were the results of the questionnaire used to group students into four categories of personality types, the results of the student's story problem solving test results, and the results of the interviews of the students who were the research subjects. The results showed that in solving the twovariable linear equation system material story problems, students sanguinis experienced reading errors, comprehensior errors, transformation errors, process skill errors, and encoding error. Melancholy and phlegmatis students experience transformation error, process skill error, and encoding error. Koleris students experienced process skill error and encoding error.
\end{abstract}

Keywords: Error, Newman, Personality Type, SPLDV

\section{PENDAHULUAN}

Matematika merupakan salah satu dari serangkaian mata pelajaran yang mempunyai peranan penting dalam dunia pendidikan karena dapat mendukung perkembangan ilmu pengetahuan dan teknologi. Matematika menjadi dasar dari perkembangan teknologi modern yang dapat memajukan daya pikir manusia. Matematika adalah salah satu disiplin ilmu yang dapat meningkatkan kemampuan berpikir, berargumentasi, memberikan kontribusi dalam penyelesaian masalah sehari-hari [11].

Pemecahan masalah merupakan bagian yang sangat penting dalam kurikulum matematika karena dalam pembelajaran maupun penyelesaiannya, siswa dimungkinkan mendapatkan pengalaman menggunakan pengetahuan yang sudah dimiliki untuk diterapkan pada pemecahan masalah yang bersifat tidak rutin. Pemecahan masalah dalam matematika sekolah biasanya diwujudkan melalui soal cerita [9].

Soal cerita matematika merupakan soal-soal matematika yang menggunakan bahasa verbal dan umumnya berhubungan dengan kegiatan sehari-hari [12]. Penyelesaian dalam soal cerita matematika tidak hanya memperhatikan jawaban pada akhir perhitungan, tetapi juga memperhatikan penyelesaiannya. Siswa dituntut untuk bisa menyelesaikan masalah melalui kemampuannya dalam memahami, merancang, dan menyelesaikan soal cerita tersebut. Meskipun soal cerita matematika secara umum berhubungan dengan kegiatan sehari-hari tapi 
ternyata masih banyak siswa yang mengalami kesulitan dalam memecahkan soal cerita matematika. Kesulitan siswa dalam memecahkan soal cerita ini terjadi karena siswa tidak bisa memahami soal, tidak bisa membuat rencana penyelesaian atau model matematika, dan tidak bisa melaksanakan atau menyelesaikan model matematika [3]. Kesulitan siswa dalam menyelesaikan soal cerita inilah yang akhirnya menyebabkan mereka melakukan banyak kesalahan dalam penyelesaiannya. Lebih dari 50\% guru mengatakan bahwa sebagian besar siswa akan mengalami kesalahan dalam menyelesaikan soal cerita. Salah satunya adalah saat siswa dihadapkan dengan soal cerita pada materi sistem persamaan linear dua variabel [7].

Salah satu alat yang bisa digunakan untuk menganalisis kesalahan yang dilakukan oleh siswa dalam menyelesaikan soal cerita adalah dengan menggunakan analisis kesalahan berdasarkan tahapan dari Newman. Menurut Newman, kesalahan yang dilakukan oleh siswa dalam menyelesaikan soal cerita matematika dibedakan menjadi lima tipe kesalahan, yaitu: (1) reading error (kesalahan membaca), (2) comprehension error (kesalahan memahami), (3) transformation error (kesalahan transformasi), (4) process skill error (kesalahan ketrampilan proses), dan (5) encoding error (kesalahan penulisan hasil akhir) [13].

Faktor lain yang perlu diperhatikan oleh guru dalam usaha untuk meningkatkan hasil pembelajaran adalah dengan cara mengembangkan potensi siswa secara optimal. Salah satu caranya adalah dengan memahami karakteristik dari siswa. Karakteristik siswa yang dapat mempengaruhi kegiatan belajar siswa salah satunya adalah tipe kepribadian [8]. Terdapat empat tipe kepribadian yang dimiliki oleh setiap individu, yaitu tipe kepribadian sanguinis, kepribadian melankolis, kepribadian koleris, dan kepribadian phlegmatis [4]. Keempat kepribadian tersebut akan mempengaruhi sikap dan perilaku dari seseorang dalam menyesuaikan diri dan bersosialisasi dengan lingkungan yang ada di sekitarnya, termasuk saat pembelajaran. Berdasarkan penjelasan tersebut maka dianggap penting untuk memperoleh informasi tentang kesalahan yang dilakukan oleh siswa dengan tipe kepribadian yang berbeda-beda dalam menyelesaikan soal cerita materi sistem persamaan linear dua variabel berdasarkan tahapan Newman. Untuk itu dilakukan penelitian dengan judul "Analisis Kesalahan Siswa dalam Menyelesaikan Soal Cerita Sistem Persamaan Linear Dua Variabel (SPLDV) Berdasarkan Tahapan Newman Ditinjau dari Tipe Kepribadian Florence Littauer".

\section{METODE PENELITIAN}

Jenis penelitian ini menggunakan penelitian deskriptif dengan pendekatan kualitatif. Penelitian ini bertujuan untuk mendeskripsikan jenis kesalahan siswa tipe kepribadian sanguinis, melankolis, koleris, dan phlegmatis dalam menyelesaikan soal cerita sistem persamaan linear dua variabel berdasarkan analisis kesalahan Newman. Instrumen yang digunakan terdiri dari angket tipe kepribadian, soal tes, dan pedoman wawancara. Pengumpulan data dilakukan dengan memberikan angket tipe kepribadian dan soal tes kepada siswa kelas IX C SMP Nuris Jember. Hasil angket tipe kepribadian tersebut dinalisis untuk mengelompokkan siswa ke dalam tipe sanguinis, koleris, melankolis, dan phlegmatis. Analisis hasil penyelesaian dari soal tes dilakukan berdasarkan kesalahan Newman. Dari keempat kategori tipe kepribadian tersebut diambil dua siswa di setiap kategori berdasarkan siswa yang mempunyai kesalahan penyelesaian tes soal terbanyak sehingga jumlah total terdapat delapan siswa. Kedelapan siswa tersebut diwawancara untuk memperoleh informasi yang lebih mendalam tentang hasil pekerjaannya. 


\section{HASIL DAN PEMBAHASAN}

Dalam menganalisis kesalahan siswa dalam menyelesaikan soal cerita matematika, diperlukan indikator kesalahan Newman sebagai berikut.

Tabel 1. Indikator Kesalahan Menurut Newman

\begin{tabular}{|c|c|c|}
\hline No & Tipe Kesalahan & Indikator \\
\hline 1. & $\begin{array}{l}\text { Reading Error } \\
\text { (kesalahan membaca soal) }\end{array}$ & $\begin{array}{l}\text { Siswa tidak dapat membaca satuan atau } \\
\text { simbol-simbol dengan benar }\end{array}$ \\
\hline 2. & $\begin{array}{l}\text { Comprehension Error } \\
\text { (kesalahan memahami soal) }\end{array}$ & $\begin{array}{l}\text { a. Siswa tidak menuliskan apa yang } \\
\text { diketahui } \\
\text { b. Siswa menuliskan apa yang diketahui } \\
\text { namun tidak tepat } \\
\text { c. Siswa tidak menuliskan apa yang } \\
\text { ditanyakan } \\
\text { d. Siswa menuliskan apa yang ditanyakan } \\
\text { namun tidak tepat }\end{array}$ \\
\hline 3. & $\begin{array}{l}\text { Transformation Error } \\
\text { (kesalahan transformasi) }\end{array}$ & $\begin{array}{l}\text { a. Siswa tidak mampu membuat model } \\
\text { matematis dari informasi yang } \\
\text { didapatkan } \\
\text { b. Siswa salah dalam memilih rumus atau } \\
\text { metode yang digunakan untuk } \\
\text { menyelesaikan soal }\end{array}$ \\
\hline 4. & $\begin{array}{l}\text { Process Skill Error (kesalahan } \\
\text { ketrampilan proses) }\end{array}$ & $\begin{array}{l}\text { a. Siswa salah menggunakan kaidah atau } \\
\text { aturan matematika yang benar } \\
\text { b. Siswa tidak dapat memproses lebih } \\
\text { lanjut solusi dari penyelesaian soal }\end{array}$ \\
\hline & & $\begin{array}{l}\text { c. Kesalahan dalam melakukan } \\
\text { perhitungan }\end{array}$ \\
\hline 5. & $\begin{array}{l}\text { Encoding Error } \\
\text { penulisan jawaban) }\end{array}$ & $\begin{array}{l}\text { a. Tidak menuliskan hasil akhir } \\
\text { b. Siswa salah dalam menuliskan satuan } \\
\text { dari jawaban akhir } \\
\text { c. Siswa tidak menuliskan kesimpulan } \\
\text { d. Siswa menuliskan kesimpulan tetapi } \\
\text { tidak tepat }\end{array}$ \\
\hline
\end{tabular}

(dimodifikasi dari White, 2005)

Berdasarkan penelitian yang dilakukan di SMP Nuris Jember kelas IX C yang berjumlah 25 siswa didapatkan hasil pengisisan angket tipe kepribadian sebagai berikut.

Tabel 2. Hasil Penggolongan Tipe Kepribadian Subjek Penelitian

\begin{tabular}{cc} 
Tipe Kepribadian & Banyak Siswa \\
\hline Sanguinis $(\mathrm{SS})$ & 3 \\
Melankolis $(\mathrm{MS})$ & 7 \\
Koleris $(\mathrm{KS})$ & 4
\end{tabular}


Tes soal yang digunakan dalam penelitian ini yaitu dua soal cerita materi sistem persamaan linear dua variabel dengan indikator yang berbeda yaitu membuat model matematika sistem persamaan linear dua variabel dari soal cerita dan menyelesaikannya untuk memperoleh solusi permasalahan yang diberikan dan membuat model matematika sistem persamaan linear dua variabel dari soal cerita berdasarkan ciri-ciri yang ditemukan dan menyelesaikannya untuk memperoleh solusi permasalahan yang diberikan.

\section{Kesalahan Membaca}

Berikut ini adalah contoh kesalahan membaca yang dialami oleh siswa SS2.

Berikut merupakan kutipan wawancara dengan siswa SS2.

P01 : Coba perhatikan soal nomor 1. Tolong bacakan soal tersebut!

SS2.1 : : (membaca soal dengan jelas)

P02 : Tadi Anda tidak membaca satuan mata uang pada $\mathrm{Rp} 17.000$ dan Rp 18.000. Mengapa Anda tidak membacanya dengan satuan mata uangnya?

SS2.2 : Iya, Bu. Saya kebiasaan tidak baca rupiahnya. Kan nanti yang digunakan saat menghitung hanya angkanya saja.

Berdasarkan kutipan wawancara diatas, siswa SS2 tidak membacakan satuan nominal uang, melainkan hanya nominalnya saja, dikarenakan siswa SS2 tidak terbiasa membaca satuan mata uang rupiah (Rp). Oleh karena itu, dapat disimpulkan bahwa siswa SS2 mengalami kesalahan membaca soal.

\section{Kesalahan Memahami Soal}

Berikut ini adalah contoh kesalahan memahami soal yang dialami oleh siswa SS1. Hasil tes dan wawancara siswa SS1 disajikan pada Gambar 1 dan kutipan wawancara berikut.

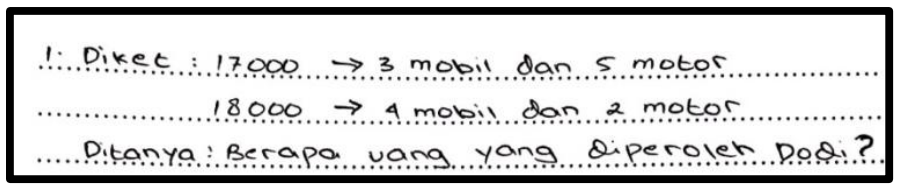

Gambar 1. Kesalahan Memahami Soal SS1

Berdasarkan hasil tes yang ada pada Gambar 1, terlihat bahwa siswa SS1 tidak menuliskan dengan lengkap apa yang ditanyakan pada soal. Berikut adalah kutipan wawancara dengan siswa SS1.

P03 : Baik kalau begitu, apa yang diketahui dari soal tersebut?

SS1.3 : Yang diketahui itu Dodi mendapatkan uang Rp. 17.000,00 kalau kendarannya yang diparkir adalah 3 mobil sama 5 motor. Terus yang didapatkan Dodi itu uangnya Rp. 18.000,00 kalau kendarannya yang diparkir adalah 4 mobil dan 2 motor.

P04 : Baik. Lalu apa yang ditanyakan dari soal tersebut?

SS1.4 : Berapa banyak uang yang diperoleh Dodi?

P05 : Coba diperhatikan kembali soalnya. Apa yang ditanyakan?

SS1.5 : Oh kurang jika yang parkir 10 mobil dan 15 motor, Bu. 
Berdasarkan hasil tes dan kutipan wawancara di atas, dapat disimpulkan bahwa siswa dengan kode SS1 mengerti apa yang diketahui dan ditanyakan tetapi tidak menuliskannya dengan lengkap dan benar, dikarenakan tidak menuliskan informasi berapa jumlah mobil dan motor yang akan dicari pada soal. Oleh karena itu, dapat disimpulkan bahwa siswa sanguinis dengan kode SS1 mengalami kesalahan memahami soal.

\section{Kesalahan Transformasi}

Berikut ini adalah contoh kesalahan transformasi yang dialami oleh siswa PS1. Hasil tes dan wawancara siswa PS1 disajikan pada Gambar 2 dan kutipan wawancara berikut.

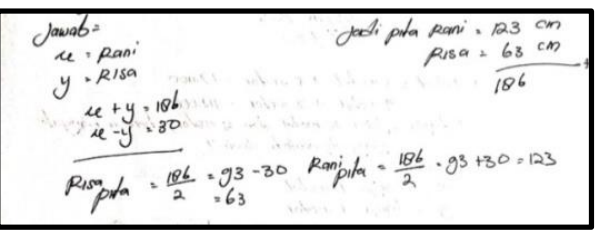

\section{Gambar 2. Kesalahan Transformasi Soal Siswa PS1}

Dari hasil tes pada Gambar 2, terlihat bahwa siswa PS1 melakukan kesalahan dalam memilih rumus atau metode yang digunakan untuk menyelesaikan soal. Siswa PS1 tidak melakukan penyelesaian soal dengan menggunakan metode subsitusi, metode eliminasi, metode campuran, maupun metode grafik. Berikut kutipan wawancara dengan siswa PS1.

$\begin{array}{ll}\text { P010 } & \text { Mengapa Anda tidak melanjutkan mengerjakan menggunakan model } \\ & \text { matematika yang sudah ditemukan? } \\ \text { PS1.10 } & : \text { Saya lupa gimana rumusnya kalau begini Bu. }\end{array}$

Berdasarkan kutipan wawancara di atas, siswa melakukan kesalahan dalam memilih rumus atau metode yang digunakan karena merasa kesulitan untuk menentukan langkah selanjutnya setelah membuat model soal. Oleh karena itu dapat disimpulkan bahwa siswa PS1 mengalami kesalahan transformasi soal.

\section{Kesalahan Keterampilan Proses}

Berikut ini adalah contoh kesalahan keterampilan proses yang dialami oleh siswa MS1. Hasil tes dan wawancara siswa MS1 disajikan pada Gambar 3 dan kutipan wawancara berikut.

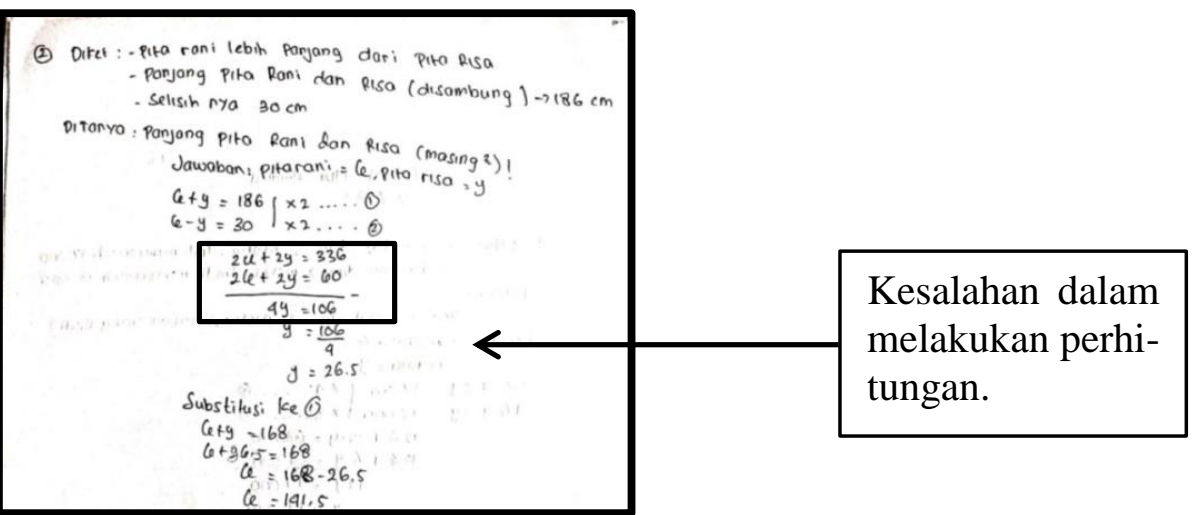

Gambar 3. Kesalahan Keterampilan Proses MS1 
Berikut kutipan wawancara dengan siswa MS1.

P010 : Baik. Coba sekarang perhatikan lagi penyelesaian dari soal tersebut. Apakah Anda sudah yakin dengan perhitungan yang Anda lakukan?

MS1.10 : Insya Allah sudah.

Berdasarkan kutipan wawancara di atas, siswa MS1 melakukan kesalahan menghitung pada operasi pengurangan dan perkalian dikarenakan kurang teliti dalam menghitung, yang mengakibatkan siswa mengalami kesalahan dalam menentukan hasil akhir. Oleh karena itu dapat disimpulkan bahwa siswa MS1 mengalami kesalahan keterampilan proses.

\section{Kesalahan Penulisan Jawaban Akhir}

Berikut ini adalah contoh kesalahan penulisan jawaban akhir yang dialami oleh siswa KS1. Hasil tes dan wawancara siswa KS1 disajikan pada Gambar 4 dan kutipan wawancara berikut.

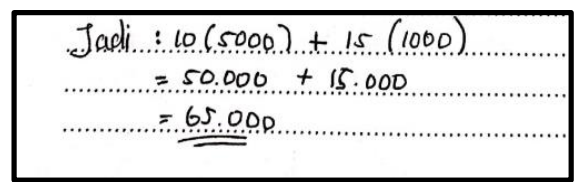

\section{Gambar 4. Kesalahan Penulisan Jawaban Akhir Siswa KS1}

Dari hasil tes pada Gambar 4, terlihat bahwa siswa KS1 salah menuliskan hasil akhir dan tidak menuliskan kesimpulan setelah menemukan hasil akhir. Berikut kutipan wawancara dengan siswa KS1.

P015 : Anda sudah mendapatkan jawaban akhir, mengapa Anda tidak menuliskannya?

KS1.15 : Ini ditulis, Bu (menunjuk lembar jawabannya).

P016 : Iya. Tapi apakah sudah menuliskan jika itu adalah uang yang diperoleh Dodi jika kendaraan yang parkir adalah 10 mobil dan 15 motor?

KS1.16 : Hehehe iya nggak. Terburu-buru saya Bu.

Berdasarkan hasil tes dan kutipan wawancara di atas, siswa KS1 tidak menuliskan kesimpulan setelah menemukan hasil akhir dikarenakan siswa terburu-buru dan tidak menyimpulkan dari apa yang ditanyakan dalam soal. Oleh karena itu, siswa KS1 mengalami kesalahan penulisan jawaban akhir.

Berdasarkan soal tes materi Sistem Persamaan Linear Dua Variabel yang diberikan kepada seluruh siswa kelas IX C SMP Nuris Jember, sesuai dengan penelitian yang telah ditetapkan sebelumnya bahwa subjek yang diwawancarai adalah 2 siswa sanguinis, 2 siswa melankolis, 2 siswa koleris, dan 2 siswa phlegmatis sehingga terdapat total 8 subjek pada penelitian ini. Dari hasil analisis jawaban pada lembar tes siswa, ditemukan jenis kesalahan yang dilakukan oleh siswa berdasarkan tahapan Newman yaitu kesalahan membaca (reading error), kesalahan memahami soal (comprehension error), kesalahan transformasi soal (transformation error), kesalahan keterampilan proses (process skill error), dan kesalahan penulisan jawaban akhir (encoding error). Bentuk kesalahan yang dilakukan siswa dalam menyelesaikan soal cerita sistem persamaan linear dua variabel berdasarkan tahapan 
Newman ditinjau dari tipe kepribadian Florence Littauer secara lebih rinci dapat dilihat pada Tabel 3 .

Tabel 3. Jenis Kesalahan Siswa berdasarkan Tahapan Newman ditinjau dari Tipe Kepribadian Florence Littauer

\begin{tabular}{cccc}
\hline \multirow{2}{*}{ Kode Siswa } & & \multicolumn{2}{c}{ Jenis Kesalahan } \\
\cline { 2 - 4 } & & Soal Nomor 1 & Soal Nomor 2 \\
\cline { 2 - 4 } Sanguinis & $\mathrm{SS} 1$ & $\mathrm{~B}, \mathrm{D}, \mathrm{E}$ & $\mathrm{B}, \mathrm{C}, \mathrm{D}, \mathrm{E}$ \\
\hline \multirow{2}{*}{ Melankolis } & $\mathrm{SS} 2$ & $\mathrm{~A}, \mathrm{~B}, \mathrm{C}, \mathrm{D}, \mathrm{E}$ & $\mathrm{B}, \mathrm{C}, \mathrm{D}, \mathrm{E}$ \\
\hline \multirow{2}{*}{ Koleris } & $\mathrm{MS} 1$ & $\mathrm{C}, \mathrm{E}$ & $\mathrm{D}, \mathrm{E}$ \\
\cline { 2 - 4 } & $\mathrm{MS} 2$ & $\mathrm{D}, \mathrm{E}$ & $\mathrm{C}, \mathrm{D}, \mathrm{E}$ \\
\hline \multirow{2}{*}{ Phlegmatis } & $\mathrm{KS} 1$ & $\mathrm{D}, \mathrm{E}$ & $\mathrm{D}, \mathrm{E}$ \\
\hline & $\mathrm{KS} 2$ & $\mathrm{D}, \mathrm{E}$ & $\mathrm{D}, \mathrm{E}$ \\
\hline
\end{tabular}

Keterangan:

A : Kesalahan Membaca

B : Kesalahan Memahami Soal

C : Kesalahan Transformasi Soal

D : Kesalahan Keterampilan Soal

E : Kesalahan Penulisan Jawaban Akhir

Berdasarkan Tabel 2, dapat dideskripsikan jenis kesalahan siswa dalam menyelesaikan soal materi sistem persamaan linear dua variabel adalah sebagai berikut.

\section{Jenis Kesalahan Siswa Sanguinis dalam Menyelesaikan Soal Materi Sistem Persamaan Linear Dua Variabel}

Siswa sanguinis pada penelitian ini yaitu siswa SS1 dan SS2 dalam menyelesaikan soal cerita materi sistem persamaan linear dua variabel cenderung hanya mampu mengerjakan soal hingga tahap memodelkan permasalahan dalam bentuk model matematika saja. Siswa sanguinis mengalami kesalahan membaca soal, kesalahan memahami soal, kesalahan transformasi soal, kesalahan keterampilan proses, dan kesalahan penulisan jawaban akhir. Hal ini sesuai dengan hasil penelitian yang menyimpulkan bahwa kesalahan siswa dalam mengerjakan soal matematika terjadi pada tahap transformasi, ketrampilan proses, dan penulisan hasil akhir yang terjadi karena faktor pengetahuan [10].

Kesalahan membaca soal terjadi pada siswa yaitu tidak membacakan satuan nominal uang. Kesalahan memahami soal terjadi pada siswa yaitu tidak menuliskan dengan lengkap apa yang diketahui dan ditanyakan. Kesalahan transformasi soal terjadi pada siswa, yaitu siswa tidak membuat model matematika dari soal dan salah dalam memilih rumus atau metode yang akan digunakan dalam mengerjakan soal. Kesalahan keterampilan proses juga dialami oleh siswa yaitu tidak mampu melanjutkan proses perhitungan hingga selesai. Selain itu, kesalahan penulisan jawaban akhir juga terjadi pada siswa yaitu tidak menarik kesimpulan dari soal karena siswa tidak menemukan hasil akhir. Hal ini sesuai dengan hasil penelitian yang menunjukkan bahwa siswa sanguinis dalam mengerjakan soal matematika 
dapat menyelesaikan dengan penyelesaian yang singkat, namun menyerah jika tidak merasa bisa atau tidak senang dengan soal yang diberi [5]. Hal ini menunjukkan bahwa siswa tidak tertib dalam mengerjakan soal yang diberikan dan sesuai dengan pendapat Littauer (1996) yang mengatakan bahwa kelemahan dari seseorang dengan tipe kepribadian sanguinis adalah terlalu banyak bicara, pelupa, tidak tertib, dan tidak dewasa.

\section{Kesalahan Siswa Melankolis dalam Menyelesaikan Soal Materi Sistem Persamaan Linear Dua Variabel}

Siswa melankolis pada penelitian ini yaitu siswa MS1 dan MS2 dalam menyelesaikan soal cerita materi sistem persamaan linear dua variabel cenderung hanya berusaha menyelesaikan permasalahan dalam soal semampunya saja. Siswa MS1 dan MS2 mengalami kesalahan transformasi soal, keterampilan proses, dan kesalahan penulisan jawaban akhir. Hal ini sesuai dengan hasil penelitian yang menyimpulkan bahwa kesalahan siswa dalam mengerjakan soal matematika terjadi pada tahap transformasi, ketrampilan proses, dan penulisan hasil akhir yang terjadi karena faktor pengetahuan [10].

Kesalahan transformasi soal dialami oleh siswa yaitu salah dalam memilih rumus atau metode yang akan digunakan. Kesalahan keterampilan proses dialami oleh siswa yaitu kesalahan dalam proses menghitung sehingga menemukan hasil akhir yang tidak tepat. Selain itu, siswa juga mengalami kesalahan penulisan jawaban akhir yaitu menuliskan kesimpulan tetapi tidak tepat. Hal ini sesuai dengan hasil penelitian yang menyimpulkan bahwa siswa melankolis saat mengerjakan soal matematika dapat dengan baik memahami makna dari soal dan tahu apa yang harus dilakukan pertama namun masih kurang baik dalam hal perhitungan [5]. Hal ini juga sesuai dengan hasil penelitian yang menunjukkan bahwa dengan tipe kebpibadian siswa melankolis cenderung kurang teliti saat mengerjakan soal meskipun memberikan jawaban secara rinci [2]. Hal ini tidak sesuai dengan pendapat Littauer (1996) yang mengatakan bahwa seseorang dengan tipe kepribadian melankolis memiliki sifat yang teliti, serius, tekun, dan analitis.

\section{Kesalahan Siswa Koleris dalam Menyelesaikan Soal Materi Sistem Persamaan Linear Dua Variabel}

Siswa koleris pada penelitian ini yaitu siswa KS1 dan KS2 dalam menyelesaikan soal cerita materi sistem persamaan linear dua variabel berusaha menyelesaikan permasalahan dalam soal hingga menemukan hasil akhir. Siswa KS1 dan KS2 mengalami kesalahan keterampilan proses dan kesalahan penulisan jawaban akhir. Hal ini sesuai dengan hasil penelitian yang mengatakan bahwa siswa sering melakukan kesalahan ketrampilan proses dan kelasahan penulisan jawaban akhir dalam mengerjakan soal matematika [6][10].

Kesalahan keterampilan proses yang dialami oleh siswa yaitu kesalahan dalam proses menghitung sehingga menemukan hasil akhir yang tidak tepat. Hal ini sesuai dengan hasil penelitian yang menyimpulkan bahwa siswa dengan tipe kepribadian koleris cenderung terburu-buru dalam mengambil keputusan saat mengerjakan soal yang diberikan. Hal ini sesuai dengan pendapat Littauer (1996) yang mengatakan bahwa seseorang dengan tipe kepribadian koleris memiliki sifat yang sulit untuk bisa santai [1]. Selain itu, siswa juga mengalami kesalahan penulisan jawaban akhir, yaitu tidak menuliskan kesimpulan setelah menemukan hasil akhir. 


\section{Kesalahan Siswa Phlegmatis dalam Menyelesaikan Soal Materi Sistem Persamaan Linear Dua Variabel}

Siswa phlegmatis pada penelitian ini yaitu siswa PS1 dan PS2 dalam menyelesaikan soal cerita materi sistem persamaan linear dua variabel cenderung hanya berusaha menyelesaikan permasalahan dalam soal semampunya saja. Siswa PS1 dan PS2 mengalami kesalahan transformasi soal, kesalahan keterampilan proses, dan kesalahan penulisan jawaban akhir. Hal ini sesuai dengan hasil penelitian yang menyimpulkan bahwa kesalahan siswa dalam mengerjakan soal matematika terjadi pada tahap transformasi, ketrampilan proses, dan penulisan hasil akhir yang terjadi karena faktor pengetahuan [10].

Kesalahan transformasi soal yang dialami oleh siswa yaitu salah dalam memilih rumus atau metode yang akan digunakan. Kesalahan keterampilan proses dialami oleh siswa yaitu tidak melanjutkan proses perhitungan penyeleseaian dari soal yang diberikan. Selain itu, kesalahan penulisan jawaban akhir terjadi pada siswa yaitu tidak menarik kesimpulan dari soal. Hal ini sesuai dengan hasil penelitian yang menyimpulkan bahwa siswa dengan tipe kepribadian phlegmatis cenderung mengerjakan soal yang diyakini benar dan memilih untuk tidak menjawab soal jika memang siswa tersebut merasa tidak mampu menyelesaikan soal tersebut [5]. Hal ini sesuai dengan Littauer (1996) yang mengatakan bahwa siswa dengan tipe kepribadian phlegmatis cenderung damai, tidak tergesa-gesa, kurang adanya motivasi, sering menunda-menunda atau menggantungkan masalah, cenderung tidak mau susah, dan tidak berpendirian. Tidak mau mencoba dan berusaha mengerjakan soal menandakan bahwa siswa phlegmatis dalam hal ini cenderung tidak mau susah dan kurang termotivasi dalam mengerjakan soal tersebut.

\section{KESIMPULAN}

Berdasarkan hasil penelitian dan pembahasan yang telah diuraikan, dapat disimpulkan bahwa siswa sanguinis dalam menyelesaikan soal Sistem Persamaan Linear Dua Variabel cenderung mengalami kesalahan membaca soal (reading error), kesalahan memahami soal (comprehensior error), kesalahan transformasi soal (transformation error), kesalahan ketrampilan proses (process skill error), dan kesalahan penulisan jawaban akhir (encoding error). Siswa melankolis dan siswa phlegmatis dalam menyelesaikan soal Sistem Persamaan Linear Dua Variabel cenderung mengalami kesalahan transformasi soal (transformation error), kesalahan ketrampilan proses (process skill error), dan kesalahan penulisan jawaban akhir (encoding error). Siswa koleris dalam menyelesaikan soal Sistem Persamaan Linear Dua Variabel cenderung mengalami kesalahan ketrampilan proses (process skill error) dan kesalahan penulisan jawaban akhir (encoding error).

Bagi guru, sebaiknya dalam proses pembelajaran lebih banyak memberikan contoh soal dan latihan soal yang bervariasi untuk melatih keterampilan siswa dalam memecahkan suatu permasalahan sehingga dapat membantu meminimalisir kesalahan yang dilakukan siswa dalam menyelesaikan soal. Selain itu, guru juga lebih memperhatikan siswa sanguinis dan phlegmatis dalam mengerjakan sebuah soal, dikarenakan siswa sanguinis cenderung mudah menyerah dan menjawab tanpa memahami soal sedangkan siswa phlegmatis cenderung santai, mengerjakan sebisanya saja dan mudah menyerah jika mengalami kesulitan. Bagi peneliti lain, sebaiknya mengembangkan penelitian ini dengan melakukan penelitian lanjutan. 


\section{DAFTAR PUSTAKA}

[1] Anam, M. K., Suharto, Murtikusuma, R. P., Hobri, \& Oktavianingtyas, E. (2018). Analisis Kemampuan Pemecahan Masalah Matematika Siswa Berdasarkan Teori APOS (Action, Process, Object, Schema) Ditinjau dari Tipe Kepribadian Florence Littauer. Kadikma, 9(2), 49-58.

[2] Kamilia, I. D., Sugiarti, T., Trapsilasiwi, D., Susanto, \& Hobri. (2018). Analisis Level Berpikir Siswa Berdasarkan Taksonomi Solo Dalam Menyelesaikan Soal Cerita SPLDV Ditinjau Dari Tipe Kepribadian Florence Littuer. Kadikma, 9(2), 165174.

[3] Layn, R., \& Kahar, S. (2017). Jurnal Math Educator Nusantara ( JMEN ) Analisis Kesalahan Siswa Dalam Menyelesaikan Soal Cerita Matematika. Jurnal Math Educator Nusantara (JMEN), 03(02), 59-145.

[4] Littauer, F. (1996). Personality Plus. Jakarta: Binarupa Aksara.

[5] Mayasari, I., Utomo, D. P., \& Cholily, Y. M. (2018). Jurnal Kajian Pembelajaran Matematika. Jurnal Kajian Pembelajaran Matematika, 2(1), 10. http://journal2.um.ac.id/index.php/jkpm

[6] Praktitipong, N., \& Nakamura, S. (2006). Analysis of Mathematics Performance of Grade Five Students in Thailand Using Newman Procedure. Journal of International Cooperation in Education, 9(1), 111-112.

[7] Raharjo, M. (2008). Pembelajaran Soal Cerita Berkait Penjumlahan dan Pengurangan di SD. Yogyakarta: P4TK Matematika.

[8] Ramalisa, Y. (2013). Proses Berpikir Kritis Siswa SMA Tipe Thinking dalam Memecahkan Masalah Matematika. Jurnal Edumatica, 3(1), 42-47.

[9] Rindyana, B. (2013). Analisis Kesalahan Siswa dalam Menyelesaikan Soal Cerita Matematika Materi Sistem Persamaan Linear Dua Variabel berdasarkan Analisis Newman (Studi Kasus MAN Malang 2 Batu). Jurnal Ilmiah Universitas Negeri Malang, 1(2), 1-9.

[10] Singh, P., Rahman, A. A., \& Hoon, T. S. (2010). The Newman procedure for analyzing Primary Four pupils errors on written mathematical tasks: A Malaysian perspective. Procedia - Social and Behavioral Sciences, 8(5), 264-271. https://doi.org/10.1016/j.sbspro.2010.12.036

[11] Susanto, A. (2013). Teori Belajar dan Pembelajaran di Sekolah Dasar. Jakarta: Prenadamedia Group.

[12] Utami, R. W., Endaryono, B. T., \& Djuhartono, T. (2018). Kemampuan Peserta Didik dalam Menyelesaikan Soal Cerita Matematika. Ilmiah Kependidikan, 5(3), 187-192.

[13] White, A. L. (2005). Active Mathematics In Classrooms: Finding Out Why Children Make Mistakes - And Then Doing Something to Help Them. Journal of Science and Mathematics Education in Southeast Asia, 15(4), 15-19. 